\title{
Extreme Tree Rings in Spruce (Picea abies [L.] Karst.) and Fir (Abies alba Mill.) Stands in Relation to Climate, Site, and Space in the Southern French and Italian Alps
}

\section{Christian Rolland, Carole Desplanque, and Richard Michalet}

Laboratoire Ecosystèmes Alpins, Centre de Biologie Alpine, Université Grenoble 1, BP 53 X, F - 38041 Grenoble, France.

rolland_christian@yahoo.fr

\section{Fritz H. Schweingruber}

Swiss Federal Institute for Forest, Snow and Landscape Research, CH 8903 Birmensdorf, Switzerland.

\begin{abstract}
The similarity over long distances of dendroecological pointer years (with extreme ring-widths) were studied at both regional and country scales in order to investigate the geographical extension of climate influences on tree-rings. Two common species, Norway spruce (Picea abies Karst.) and white fir (Abies alba Mill.) were compared. The regional study was carried out on 33 populations located in four alpine valleys along a climatic gradient of summer aridity (Tarentaise, Maurienne, and Briançonnais, in France, and Susa valley in Italy). For most of species and regions, several negative ring-width pointer years with abrupt growth reductions such as 1976, 1922, 1986, and 1944 were common (listed in order of decreasing importance). However, spruce growth was more reduced in 1948 than that of fir. At the country scale, some of the strongest positive (e.g., 1932, 1964, 1969) and negative (e.g., 1956, 1962, 1976, 1986) pointer years extended over the whole of France, whereas the geographic variability was explainable by the autoecology of species. At both studied scales, evident climatic interpretations such as severe winter frosts, unusual summer droughts, or excessive wet and cold springs can explain most of the negative pointer years. Conversely, most positive growth responses are caused by a local combination of favorable climatic factors rather than simple extreme events, and therefore are less efficient for wood dating.
\end{abstract}

\section{Introduction}

Dendroclimatology is an useful tool for dating the reaction of trees to geomorphologic events (Cournoyer and Filion, 1994; Lepage and Bégin, 1996) and climatic influences (Fritts, 1976; Camarero et al., 1998) such as extreme frosts (Schweingruber and Müller, 1992; Brunstein, 1996) or aridity. The relationships between tree-ring widths and climate may be studied with two classical methods, either the calculation of response functions (Fritts, 1976; Cook and Kairiukstis, 1992) or the analysis of pointer years (Schweingruber et al., 1990). The former method uses statistical techniques such as correlation between monthly climate and yearly average ring-widths, making assumptions about the probable effect of precipitation or temperature, whereas the latter tool analyses the periods of extreme changes in radial tree growth, without assumptions.

In pointer years analysis, an "event year" is usually defined as a year with a conspicous feature such as abrupt growth change (positive or negative), reaction wood, or wound (Kaennel and Schweingruber, 1995). When such an event year is observed simultaneously in several trees in the same population, it is called a "pointer year," and only these extreme growth changes are studied in this study. Pointer years can be visually detected on cores when they exceed an increase of more than $+30 \%$, or a reduction of less than $-40 \%$ compared to previous rings (Schweingruber et al., 1986). Such pointer years are particularly useful for dendrochronological dating of wood samples (Cropper, 1979). However, when samples come from different sites or species, it is sometimes difficult to cross-date them, since pointer years are known to be sensitive to geographical variability (Kelly et al., 1989) and species influence.
The main purpose of this study was to investigate the geographical variability of extreme ring widths. Increasing spatial scales were examined: a regional scale that comprises different sites located in several valleys in the French or Italian Alps (Desplanque, 1997), and a larger scale covering the entire country of France (Lebourgeois, 1997). Thus, the appearance and replication of pointer years over large scales and therefore the possibility of using pointer years for dating wood samples from distant sites was determind.

Two common coniferous species of quite comparable ecological requirements were sampled: Norway spruce (Picea abies [L.] Karst.) and white fir (Abies alba Mill.). Both are known to be sensitive to summer drought (Becker, 1988; Rolland, 1993; Guicherd, 1994; Desplanque et al., 1998), but fir is a more shade tolerant species, whereas spruce behaves as a pioneer tree.

The differences among these two species were first examined at the regional scale in four alpine valleys to identify the climatic limiting factors for the radial growth of each species. The interest of such sampling strategy with two species of comparable ecology was demonstrated for other Picea and Abies species by Villalba and Veblen (1994). Thus, the sampling sites are chosen along a gradient of summer drought that includes the ecological limits of both species. Such an ecological situation is favorable for dendroecological analysis, and more particularly to the study of pointer years (Schweingruber et al., 1991a). These regional results are compared then with those of Lebourgeois (1997) obtained for the same species in the French permanent plot network for the monitoring of forests ecosystems (RENECOFOR). 


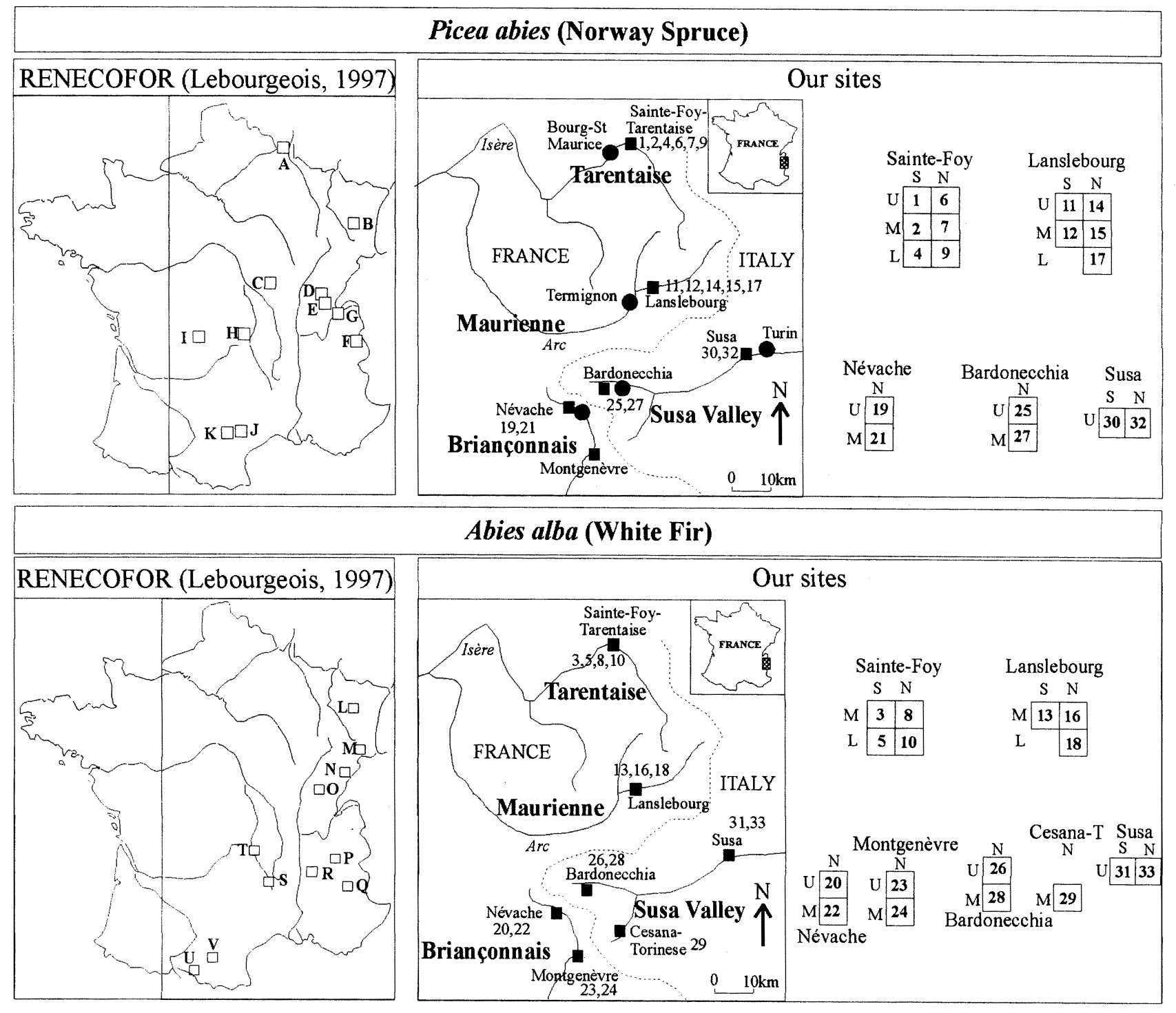

FIGURE 1. Location maps of RENECOFOR dendroecological study (Lebourgeois, 1997) in France and of our analysis in French Alps and Susa valley (Italy) for both Norway spruce and white fir. Three altitude levels (Upper, Middle, and Lower) and two aspects (North and South) were combined in the latter sampling, carried out in four valleys (in bold). Meteorological stations are indicated by circles and forest stands by squares, respectively coded with letters (RENECOFOR results) and numbers (our results).

\section{Sites and Methods}

\section{SAMPLING SITES AND CLIMATE FOR REGIONAL STUDY}

Thirty-three populations were sampled in four alpine valleys (Fig. 1): the Tarentaise, the Maurienne, the Briançonnais in France and the Susa valley in Italy (Table 1), that strongly differ with respect to summer aridity. Schematically, these regions are characterized by three main climatic features. Tarentaise and particularly Maurienne are the colder regions. Briançonnais, Susa valley, and Maurienne have the driest summers, and the wettest springs occur in Susa valley (Desplanque, 1997). Human activities have replaced subalpine forests by cultivation and pastures in some valleys (Maurienne and Tarentaise) or by pine or larch forests in Briançonnais. For that reason, the extreme bioclimatic cases (low altitude in dry regions on southern exposure) are missing in this study. Consequently, some bioclimatic influences on tree growth may be obscured by the lack of present forest under particular climatic conditions.

Each population is schematically characterized in Table 1, with its altitude, slope, aspect, and important factors influencing the ecology such as bedrock, soil, humus, and understory community. Rainfall data are not available for these forests stands and therefore have to be evaluated indirectly. For this purpose, the Gam's angles $(G)$ that expressed the increase of rainfall with altitude were successively calculated by:

$$
\operatorname{Cotg}(\mathrm{G})=\text { Rainfall }(\mathrm{mm}) / \text { Altitude }(\mathrm{m})
$$

for the whole year $\left(G_{y e}\right)$, the summer $\left(G_{s}\right)$, the winter $\left(G_{w}\right)$, and the conventional vegetation period ( $G_{v p}$, from April to August). A correction for low altitudes $(<800 \mathrm{~m})$ was used for Susa, according to Michalet (1991, in Pache et al., 1996). For example, the value $\mathrm{G}>55^{\circ}$ was considered as a limit for the beech (Fagus sylvatica $\mathrm{L}$.), excluded by excessive continentality and insufficient precipitation (Ozenda, 1985). Similarly, a value of $G_{w}$ above $65^{\circ}$ was approximately the white fir distribution threshold (Pache et al., 1996) (Fig. 2).

It is noteworthy that in the Tarentaise (Gensac, 1988) and in the Maurienne valleys (Bartoli, 1966), fir is absent at higher 


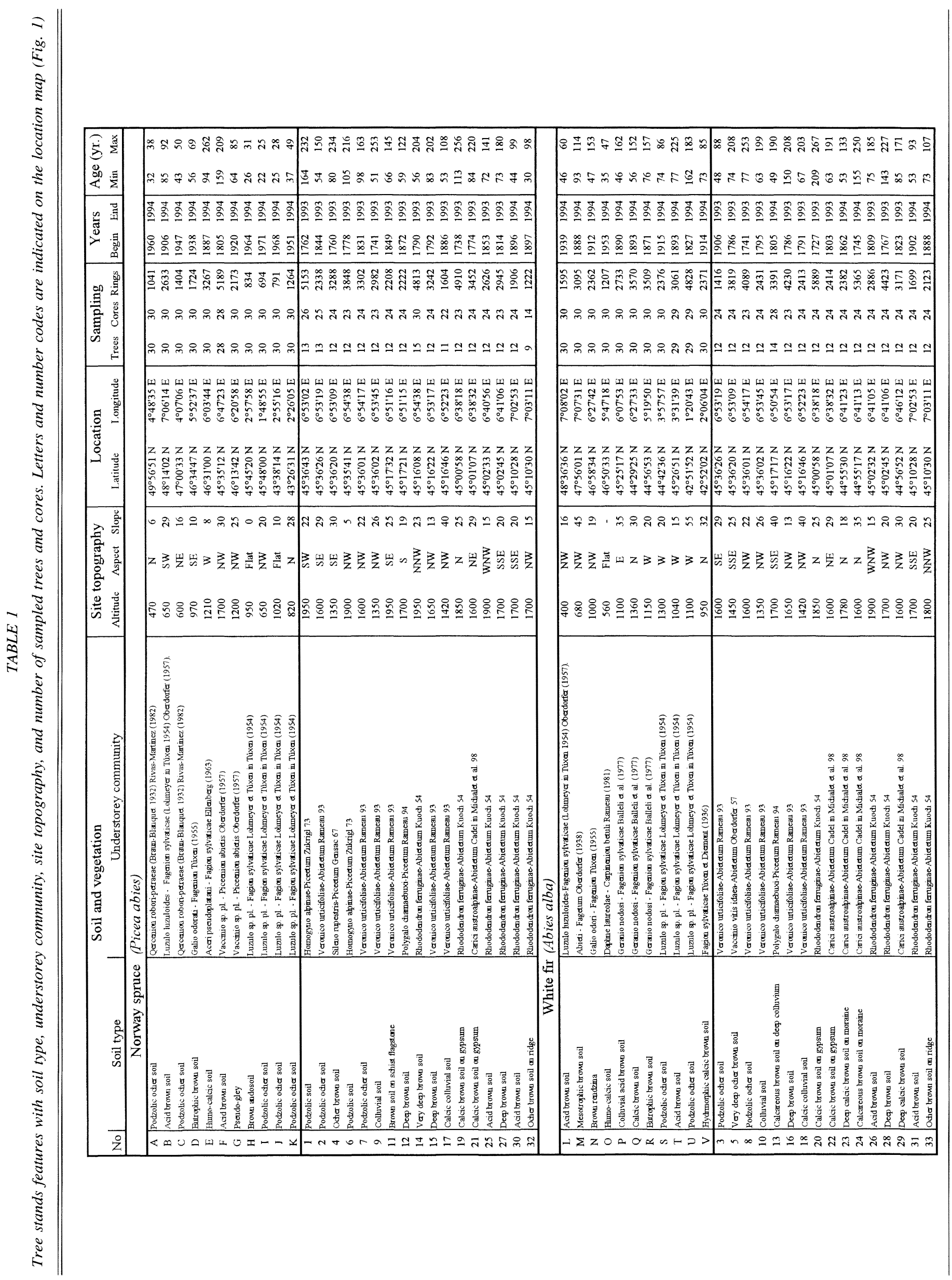

C. Rolland et Al. / 3 


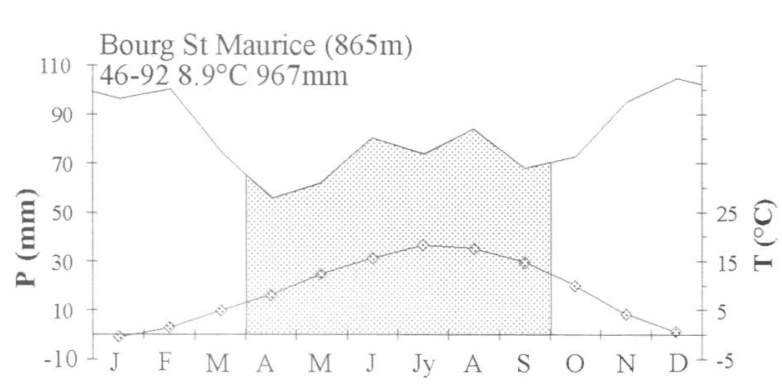

MAURIENNE

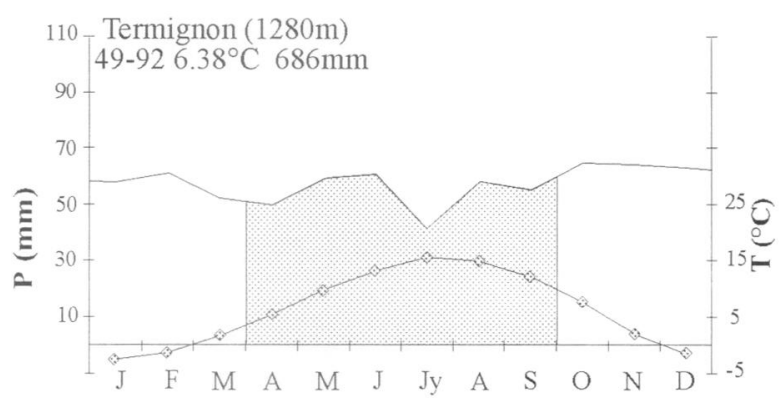

BRIANÇONNAIS

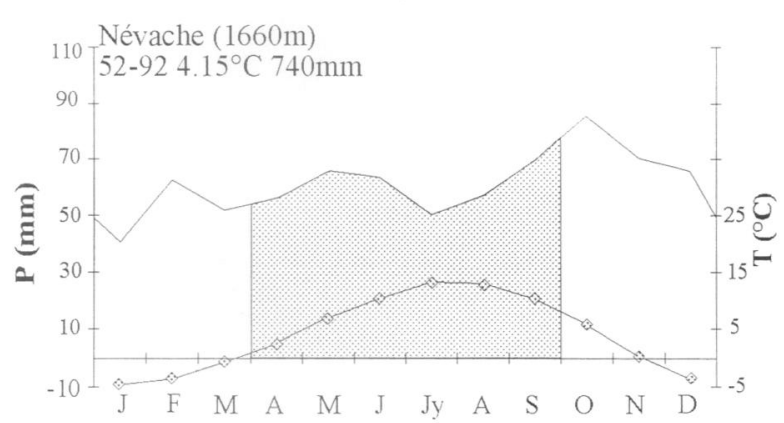

SUSA VALLEY

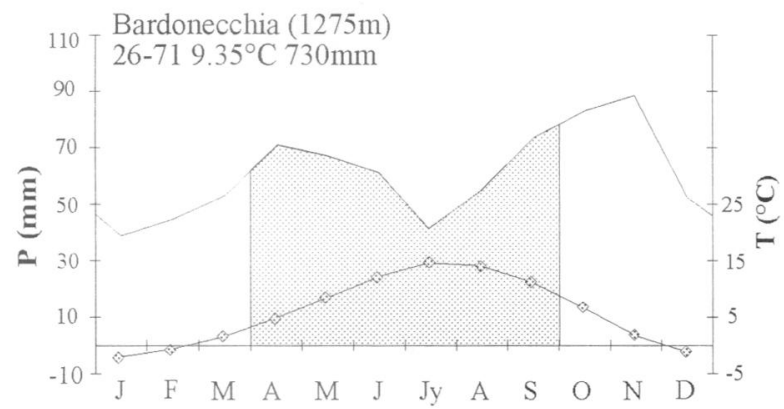

\section{SUSA VALLEY}

Susa $(501 \mathrm{~m})$

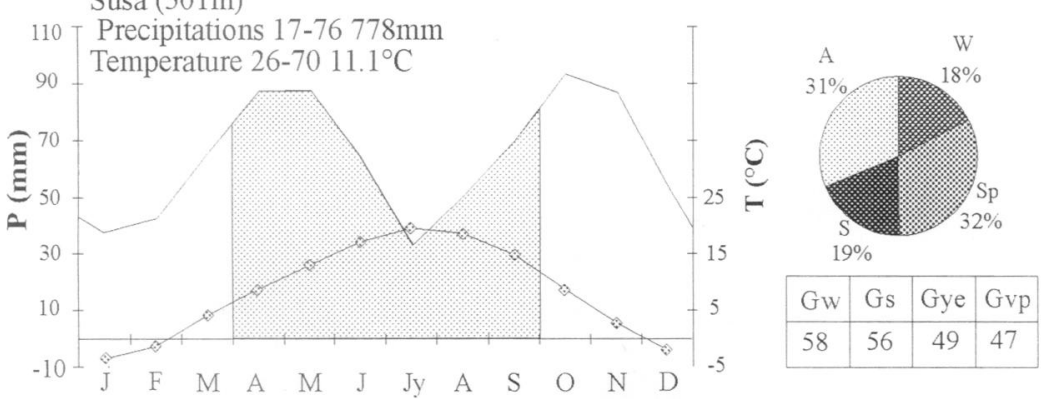

N.B. Turin 's temperatures are adjusted to Susa altitude (gradient : $-0,55^{\circ} \mathrm{C} / 100 \mathrm{~m}$ )
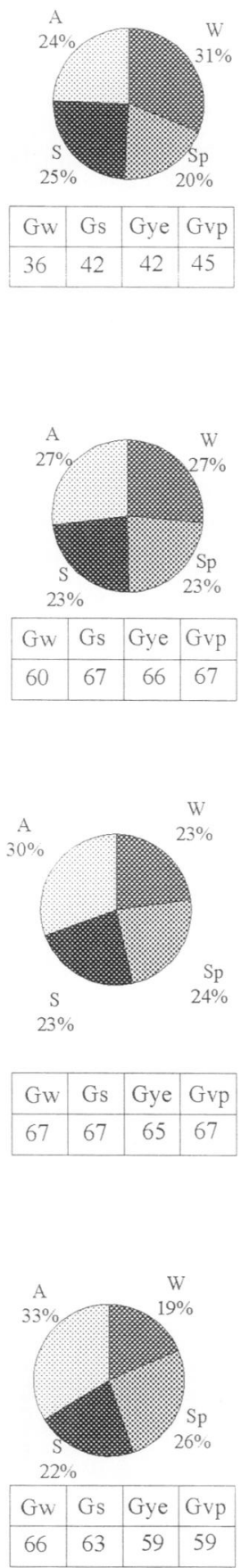

FIGURE 2. Mean monthly precipitation and air temperature in the four studied valleys. Each pie chart for seasonal precipitation was divided into 4 periods: $S p=$ spring (March-May), $S=$ summer (JuneAugust), $A=$ autumn (September-November), and $W=$ winter (December-February). Gams coefficients $(G)$ are given for winter $\left(G_{w}\right)$, summer $\left(G_{s}\right)$, whole year $\left(G_{v e}\right)$, and vegetative period $\left(G_{v p}\right)$ from April to August (see text for calculation method).

4 / Arctic, Antarctic, And Alpine Research 
altitudes (above $1800 \mathrm{~m}$ ). Moreover, in the Briançonnais (the driest part of the French Alps), the two species are not present on southern slopes. Furthermore, spruce is absent on milder northern slopes in Montgenèvre (Briançonnais), because this area is excessively dry for that species (Cadel, 1980).

\section{POINTER YEARS CALCULATIONS FOR REGIONAL STUDY}

For each population, two cores were taken in 1993-1994 at breast height $(1.3 \mathrm{~m})$ on 12 dominant trees per species. All the ring-widths were measured and cross-dated. Ring-width measurements were made to a $0.01-\mathrm{mm}$ precision, using a binocular microscope linked to a digitalizing tablet. For each individual core, the mean sensitivity (MS) was calculated using the Douglass method (in Fritts, 1976) by:

$$
M S=\frac{\sum_{i=1}^{i=N} \frac{\left|C_{i+1}-C_{i}\right|}{\left(C_{i+1}+C_{i}\right)}}{2(N-1)}
$$

( $\mathrm{N}=$ total amount of rings, $\mathrm{C}_{\mathrm{i}}=$ width of ring “ $\mathrm{i}$ ”).

The average and standard deviation of annual ring widths were obtained for each tree population.

For the calculation of pointer years, each ring-width value was compared with the average width of the four previous rings (Schweingruber et al., 1990) to detect negative pointer years (NPY) or positive pointer years (PPY). Three classes of abrupt growth changes were used, according to Schweingruber (1986) or Bronzini et al., (1989), defined as following:

- $-40 \%$ of reduction or $+66 \%$ of increase.

- $-55 \%$ and $+122 \%$

- $-70 \%$ and $+233 \%$.

For a given threshold, the number of trees showing a growth reduction $(\mathrm{N}-)$ or a growth increase $(\mathrm{N}+)$ were studied separately. These two values of pointer years (NPY and PPY) were then expressed in percentages of the total number of rings available per species during the same year.

\section{METEOROLOGICAL DATA}

Monthly sums of precipitation and mean temperature near the sampling sites were located in Bourg-Saint-Maurice, Termignon, Névache, Bardoneccia, Susa (Fig. 2). For longer time periods, the long series of Lyon was also used despite that it is located about $150 \mathrm{~km}$ far from the tree populations.

\section{SAMPLING SITES FOR COUNTRY SCALE STUDY}

A dendrochronological study was carried out by Lebourgeois (1997), covering the entire country of France in the "French Permanent Plot Network for the Monitoring of Forest Ecosystems" (RENECOFOR). In 22 of these stands, 328 firs and the same number of spruces were cored at breast height (Table 1). To compare results of our study with those of Lebourgeois (1997), his unusual methodology was also applied on our ring-widths measurements. Lebourgeois (1997) defined a pointer year as a ring-width variation between two consecutive rings exceeding $+10 \%$ or $-10 \%$, with at least $70 \%$ of reactive trees per population.

\section{Results and Discussion}

\section{REGIONAL STUDY}

The negative pointer years were analyzed for 33 populations. The whole measured period extends from 1731 to 1992
( $262 \mathrm{yr}$ ), but its beginning cannot be studied in details because of a lack of meteorological data required for the interpretation of pointer years, and fewer measured ring-widths. There is less confidence for older periods due to the smaller sample size. Therefore, the period 1880-1990 was analyzed here to conserve more than half of total cores when results are analysed by species.

\section{Regional Differences among Sites}

For both percentage of pointer years (Fig. 3a) and mean sensitivity of raw data master chronologies (Fig. 3b), there was a clear regional difference between two groups of valleys. The first group comprises the Tarentaise and the Maurienne, with many pointer years (both positive and negative), and high mean sensitivities. In contrast, the Briançonnais and Susa areas had fewer extreme tree rings and lower yearly variation of successive ring-widths (lower mean sensitivity). This result was unexpected since climate in Tarentaise is wetter and expected to be more favorable for fir and spruce development (Bartoli, 1966; Gensac, 1988). Moreover, the increasing variability in precipitation (from April to August) from Tarentaise to Susa valley (Fig. 2) was expected to lead to higher tree-ring mean sensitivities and more numerous pointer years in Briançonnais and Susa. Thus, bioclimatological arguments failed to explain differences among sites. This apparent paradox may be explained by the actual distribution of the species. Fir and spruce are excluded in Briançonnais and Susa valley from low altitudes in southern slopes by both summer aridity and past human pastoral activities (Desplanque, 1997). The exact role played by each of these factors is difficult to quantify due to a lack of archived sources. Considering the $M S$ and pointer years, the highest tree responses are often observed at low altitudes (for the populations no. 9, 10, 17, 18), and particularly on southern slopes (stands no. 4, 5) (Fig. 3b).

\section{Differences among Species}

Figure 4 and Table 2 show the number of positive and negative pointer years for fir and spruce. The two most important negative pointer years were 1976 and 1922 for both species (with $14.9 \%$ of all trees showing a negative pointer year [NPY]). Most of the years were not pointer years; moreover, normal periods (i.e., without pointer years) seem to form continuous sequences that persisted during several years. For the entire study period, the longest period without strong NPYs was observed during the $21 \mathrm{yr}$ from 1923 to 1943 (with less than $3.3 \%$ of reactive cores for all the sites). The next longest period was observed between 1872 and 1887 (16 yr) with less than $3.4 \%$ of cores with NPY. The periods 1910-1920 and 1890-1905 had also low disturbances. Conversely, the NPY appear to be concentrated into short periods from 2 to $3 \mathrm{yr}$, such as in 1906-07, 1921-22, 1948$50,1962-63,1974-76,1986-87$, and such as 1910-1915, 19251932 or 1982-1983 for the PPY (positive pointer years).

As observed in Table 2, both species reacted strongly and negatively in 1976, 1922, 1986, and 1944, (and a little less in 1992,1921 ). Spruce always showed a NPY when fir did, whereas several years were only observed for spruce (1948, 1962, 1991).

\section{Spatial Variability at Regional Scale}

Different populations of the same species under the same site conditions (altitude and aspect) usually reacted similarly in the entire studied area. However, in some cases, results strongly 


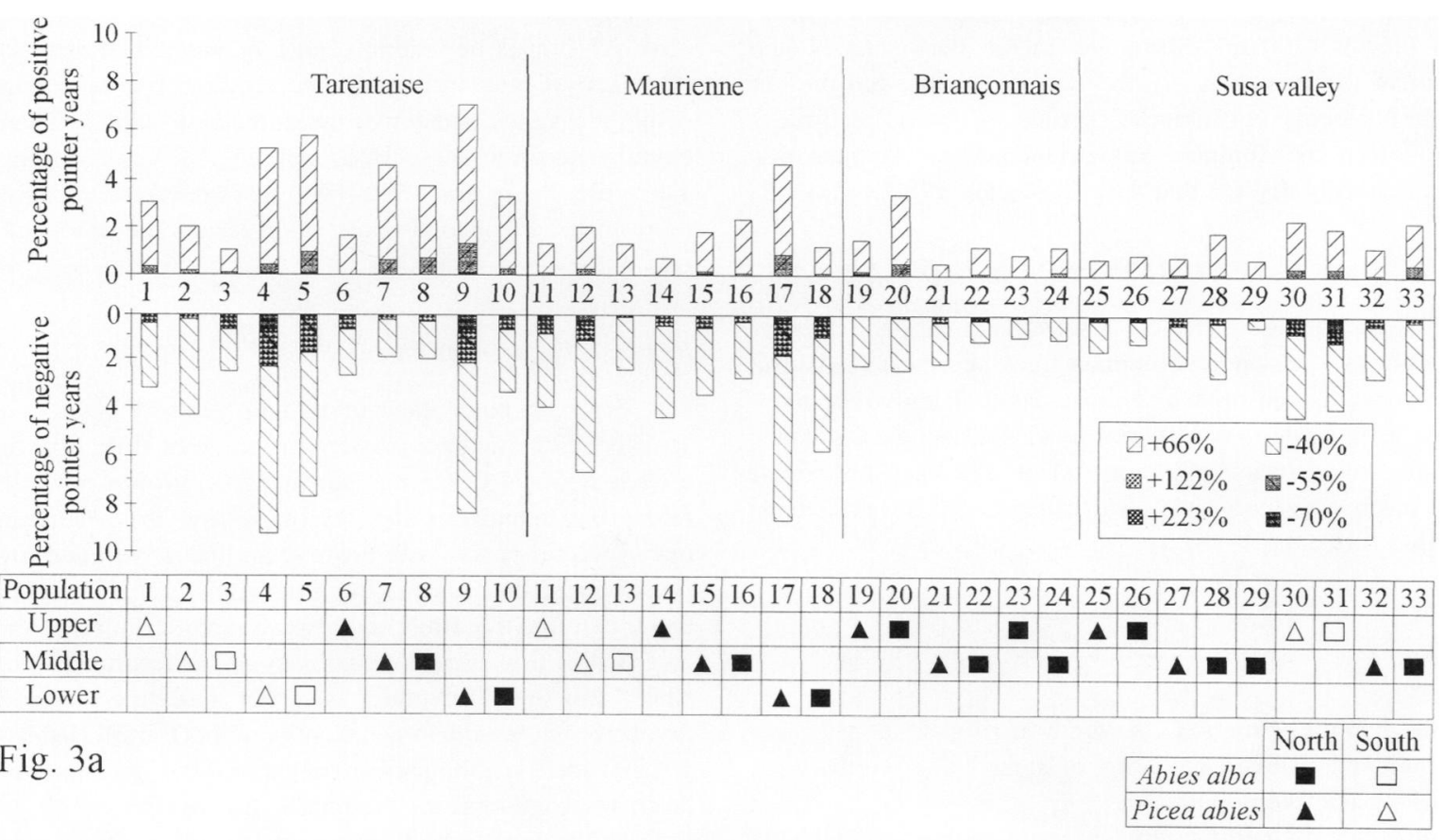

Fig. $3 b$

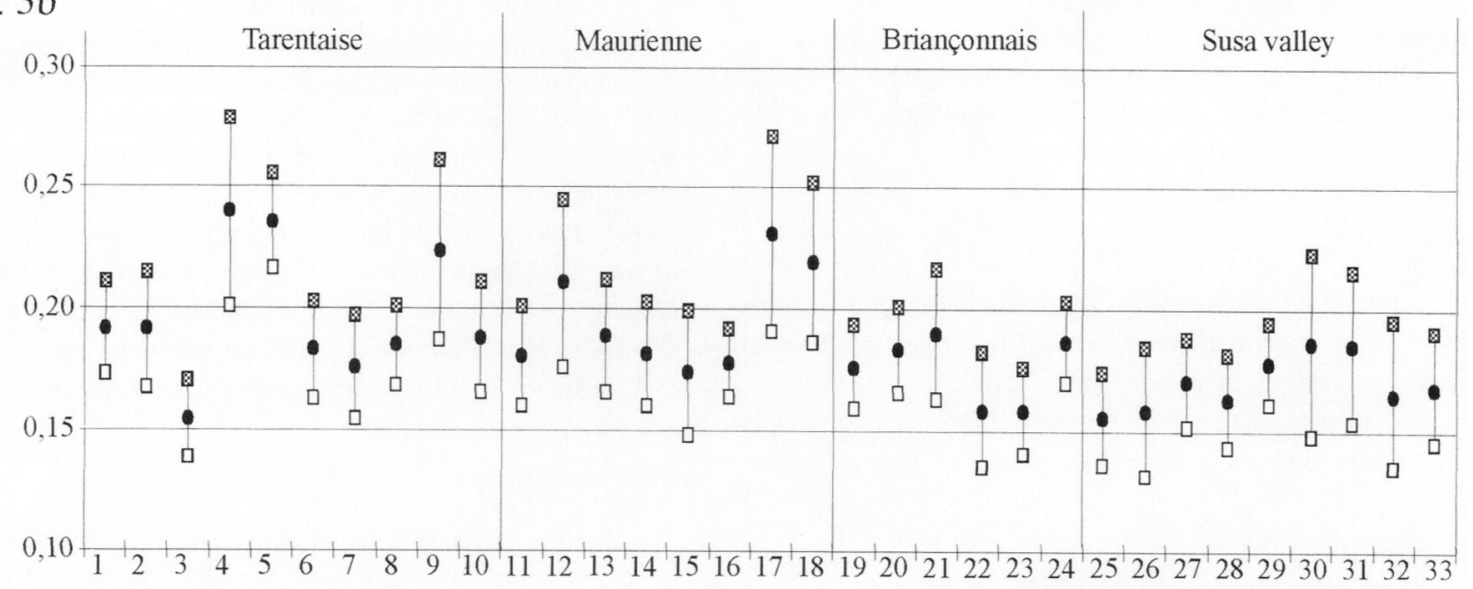

Fig. 3c

$\square$ M-Sigma $\bullet$ Mean $\otimes$ M+Sigma

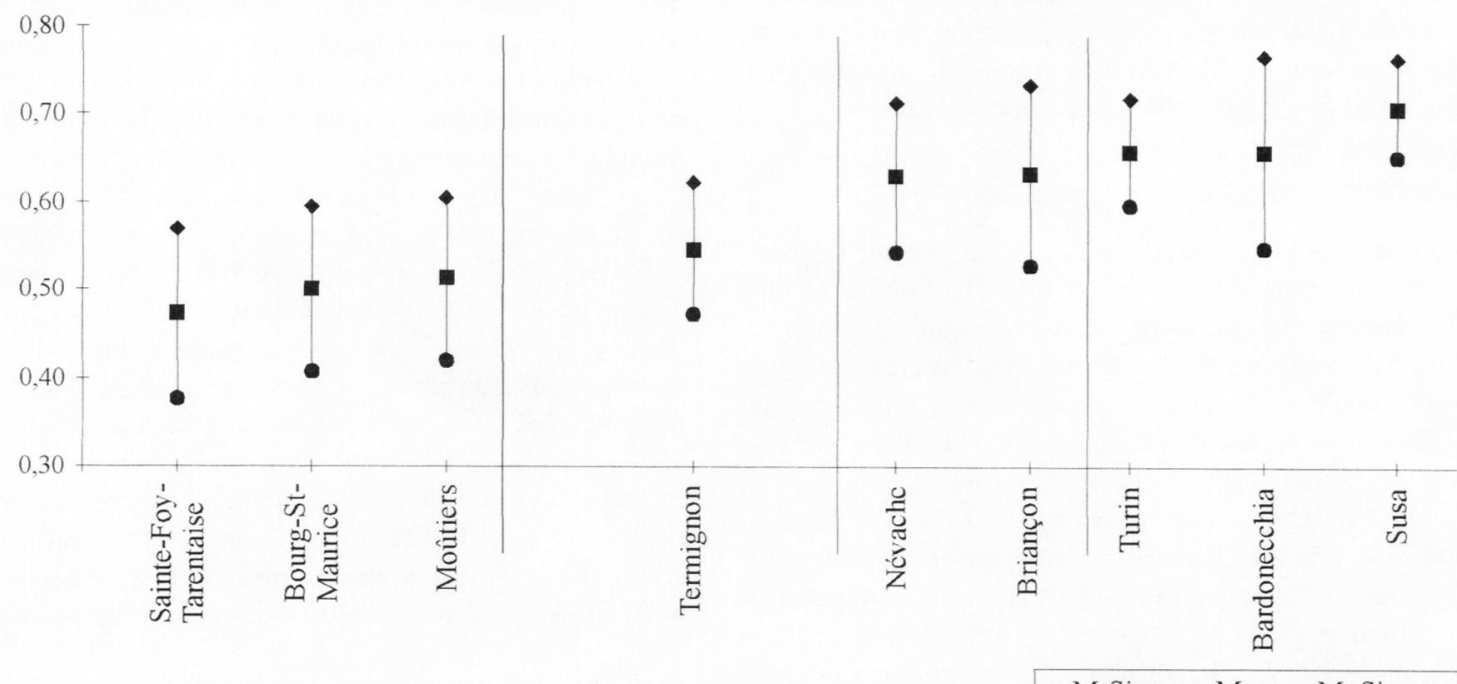

M-Sigma $\mathbf{m e a n} \bullet \mathrm{M}+$ Sigma

FIGURE 3. Percentages of pointer years (at three negative and positive thresholds) (3a) for the period 1910-1990 in each tree population in four alpine valleys (according to their altitude and aspect, with the corresponding ring-widths mean sensitivity ( $3 b$ ) (population average \pm 1 standard deviation). Precipitation coefficients of variation (3c) (standard deviation divided by mean value) are calculated from April to August for nine meteorological stations in the four studied valleys.

6 / Arctic, Antarctic, and Alpine Research

This content downloaded from 152.88.31.155 on Fri, 24 Jan 2020 13:53:00 UTC All use subject to https://about.jstor.org/terms 

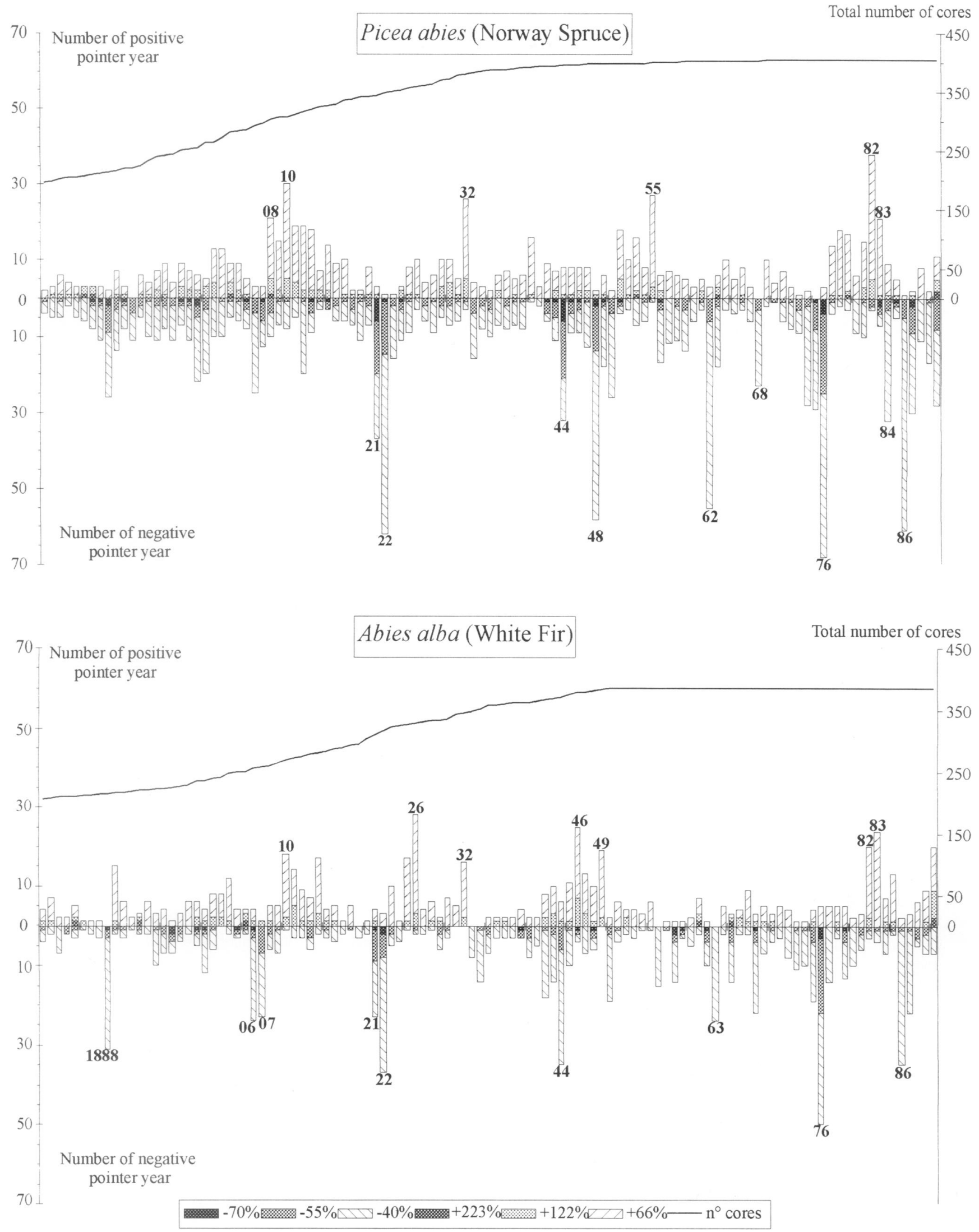

FIGURE 4. Number of pointer years at three negative and positive thresholds for Picea abies and Abies alba in the entire studied area from 1880 to 1990 (bars), with amount of available cores at a given date (curve). 
TABLE 2

Distribution of negative pointer years according to percentages of fir and spruce showing growth reductions (NPY -40\%) within 6 classes. In each class, years were listed in decreasing importance, for the period 1910-1992

\begin{tabular}{|c|c|c|c|c|c|c|c|}
\hline & \multicolumn{6}{|c|}{$\begin{array}{lll}\text { Abies alba } & --> & \text { increasing percentage of negative pointer years }-->\end{array}$} \\
\hline & & $0-1 \%$ & $1-2 \%$ & $2-4 \%$ & $4-6 \%$ & $6-8 \%$ & $>8 \%$ \\
\hline \multirow{7}{*}{$\begin{array}{l}P \\
i \\
c \\
e \\
a\end{array}$} & & \begin{tabular}{|llll}
1914 & 1982 & 1926 & 1978 \\
\end{tabular} & $1969 \quad 1951$ & $\begin{array}{ll}1965 & 1977\end{array}$ & & & \\
\hline & $0-1 \%$ & $\begin{array}{llll}1952 & 1961 & 1966 & 1964\end{array}$ & 19151941 & 19791940 & & & \\
\hline & & 19321955 & 1970 & & & & \\
\hline & & $\begin{array}{|llll|}1930 & 1936 & 1938 & 1953 \\
\end{array}$ & $1916 \quad 1929$ & \multirow{3}{*}{1972} & & & \\
\hline & $1-2 \%$ & $1917 \quad 1927 \quad 1971 \quad 1967$ & 19601983 & & 1942 & & \\
\hline & & $\begin{array}{lll}1954 & 1985 & 1931\end{array}$ & & & & & \\
\hline & & $\begin{array}{llll}1959 & 1957 & 1910 & 1937\end{array}$ & $1947 \quad 1935 \quad 1924$ & $1943 \quad 1958 \quad 1934$ & & & \\
\hline \multirow{3}{*}{$\begin{array}{l}a \\
b \\
i\end{array}$} & $2-4 \%$ & $\begin{array}{llll}1939 & 1925 & 1928 & 1920\end{array}$ & $19191981 \quad 1988$ & 197319131945 & & & \\
\hline & & 1918 & 1946 & 1980 & & & \\
\hline & $4-6 \%$ & 1949 & $\begin{array}{ll}1923 & 1989\end{array}$ & $\begin{array}{ll}1956 \quad 1933\end{array}$ & 1968 & 1963 & \\
\hline \multirow{3}{*}{$\begin{array}{l}e \\
s\end{array}$} & $6-8 \%$ & & $\begin{array}{ll}1984 \quad 1990\end{array}$ & 1974 & 1987 & & \\
\hline & & & 1912 & & $1975 \quad 1950$ & & \\
\hline & $>8 \%$ & & 1948 & $\begin{array}{ll}1962 & 1991\end{array}$ & & $1992 \quad 1921$ & $\begin{array}{ll}1976 & 1922 \\
1986 & 1944\end{array}$ \\
\hline
\end{tabular}

differed and a geographical variability appeared for some particular pointer years. For example, 1921 was a pointer year only in Tarentaise, 1956 only in Maurienne, and 1944 or 1976 in these two valleys (Fig. 6a). During 1921 (Fig. 5), a drought period occurred most everywhere in France but not in the southern Alps (Blanchard, 1922). For that reason, this pointer year was only observed in Tarentaise, and less commonly there in northern exposures. In this case, fir reacted more strongly than spruce in the southern exposure. (Abies North $=3 \%$, South $=28 \%$; Picea $\mathrm{N}$ $=7 \%, \mathrm{~S}=18 \%$ ). Lingg (1986) and Schweingruber (1986) also observed a NPY in 1921 in the Swiss Wallis. A prolonged effect was observed the following year 1922 (Bert, 1992). Therefore, sustained unfavorable climatic conditions can produce successive NPY.

During 1976 (Fig. 5), there was a high rainfall deficit in May and June in parts of France and Switzerland, including Tarentaise and Maurienne, but not Briançonnais, Névache, or Susa. This result explains why the strongest pointer year 1976 was only observed in Tarentaise and Maurienne. It may be due to drought in May-June, for both species, and enhanced by southern exposure (Abies $\mathrm{N}=9 \%, \mathrm{~S}=23 \%$; Picea $\mathrm{N}=10 \%, \mathrm{~S}=$ 29\%) (Desplanque, 1997). Thus, spruce appears to be slightly more sensitive to summer drought than fir. This NPY was also observed for fir in the French Jura (Bert, 1992), the Vosges mountains (Becker, 1988) (NE France), and in the Wallis and Swiss Jura (Schweingruber, 1986).

\section{COUNTRY SCALE STUDY}

Samples were available in all the 33 populations since 1910 , with a yearly total number of cores ranging from 790 to 565 , for compilation of Figure 6. Note that in this section, the same calculation of pointer years was applied to both our data and to RENECOFOR results to permit direct comparisons. However, for a few dates some populations do not record pointer years. It may be explained by local factors such as deep soil that may compensat for dryness or different forest densities.

\section{Spatial Variability at the Country Scale}

The four most geographically extended negative pointer years of the last $50 \mathrm{yr}$ studied here were 1956, 1962, 1976, and 1986 (Fig. 6). Three cases may be schematically distinguished: frost events (1956), dry periods (1962, 1976), and excessively wet and cold springs (1986).

- 1956 was a typical year with a frost event for spruce and fir (Schweingruber and Müller, 1992), after a warm December and January, without frost hardening. A strong cold period occurred in whole western Europe in February (Schweingruber et al., 1991b); its effect was enhanced because soil surface and roots were not protected against freezing by snow cover (Lenz et al., 1987). Spruce reacted only in Maurienne (the coldest region,) whereas fir did not show this geographic variability.

- On the contrary, 1962 and 1976 were dry years. The driest year recorded in Geneva from 1826-1987 was 1962 (April-September). Moreover, it followed the very dry summer of 1961 (July-August). Sixteen spruce populations among 24, and 18 among 29 fir stands reacted negatively. All the populations located on southern slopes and at lower altitude presented the strongest negative pointer years. On the contrary, one population of fir at high altitude (upper level in Névache) reacted positively, exactly as observed by Petitcolas (1998) for 20 subalpine populations (of spruce, cembrian pine and larch) among 37 stands. 1962 was a very dry summer year over large areas, whereas 1976 was a less extended spring dry year combined with warmth. This main difference between these two years explains the more widespread geographical extension of NPY in 1962 in both species and at both scales, whereas the 1976 drought was not so extended as the 1962 event.

- January and April 1986 were extremely wet (with rainfall ex- 

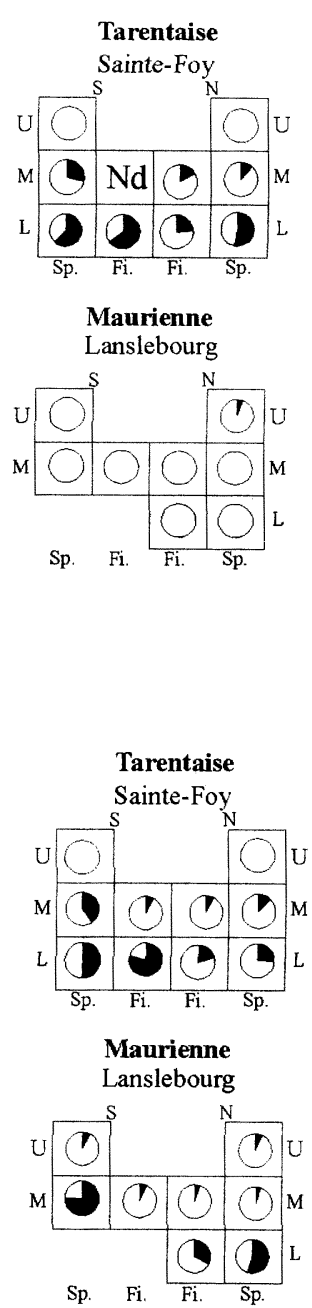

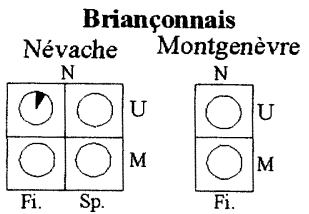

1921

Bardonecchia $\begin{array}{cc}\text { Cesana } & \text { Sorinese }\end{array}$

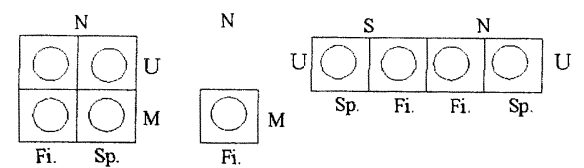

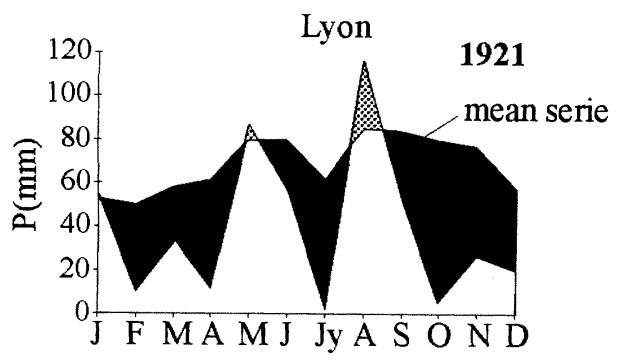

\section{Bourg Saint-Maurice \\ Tarentaise}

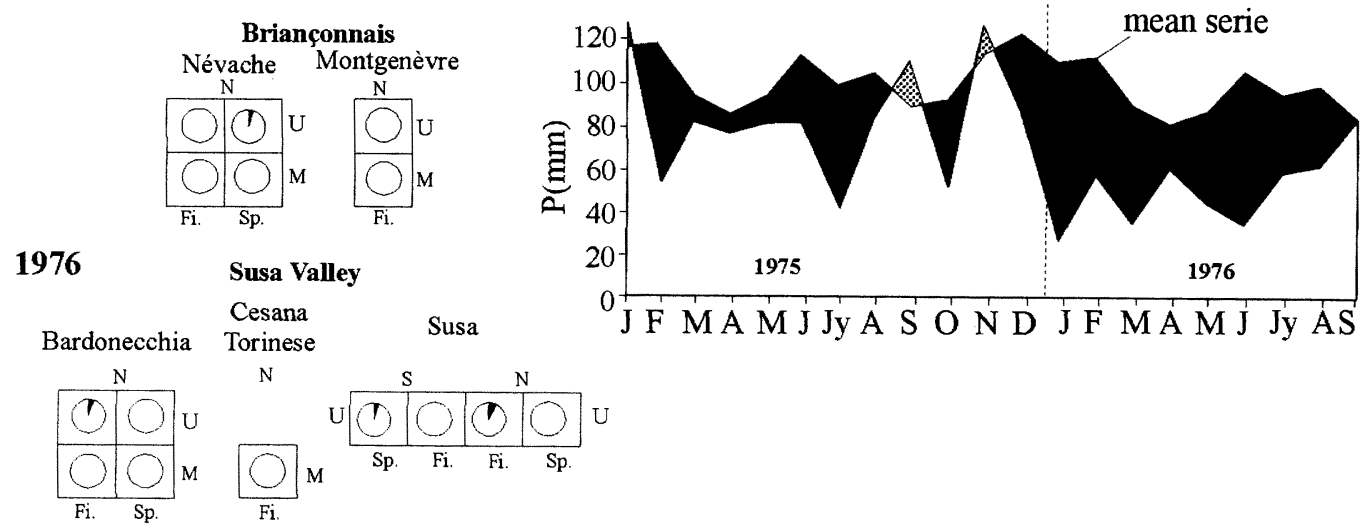

Dark part on pie chart $=\%$ of event year per population

$\mathrm{x}<$ mean $\mathrm{x}>$ mean

FIGURE 5. Spatial variability of two typical negative pointer years, 1921 (only at low altitude in the Tarentaise) and 1976 (only in Tarentaise and Maurienne) with precipitation data (mean long term data and monthly values) for previous year and current year of ring formation. Pie charts show in black the percentage of event years per population. ( $S p=$ Spruce, $F i=$ Fir; $U=U$ Uper, $M=$ Middle, $L=$ Lower; $S=$ South, $N=$ North, $n d=$ no data $)$.

ceeding the average value by more than 2 standard deviations), with very cold temperatures in February and April. Consequently, 15 spruce stands (among 28), and 18 fir stands (among 27) showed NPY, probably due to a delayed budbreak.

To conclude, only some typical negative pointer years caused by extreme and geographically extended climatic events appeared almost everywhere, regardless of the type of climatic peculiarity. However, in most cases, geographical variability occurred, dependent on species ecological requirements for growth.

The most obvious positive pointer years were in 1932, 1964, and 1969 (Fig. 6b.

- 1932 was rainy (especially in May and July) and warmer than usual, leading to larger ring widths, in particular for fir in most of sites. This was also the case in 1951 .

- After a wet March, April to June minimum temperatures in 1964 were higher than mean minimum values (by +1 or +2 standard deviations) for the regional scale meteorological data. This effect promote bud-opening (Larcher, 1995) and therefore extended the vegetative period. Positive pointer years are found only in the Alps (but with opposite results in northeastern France).

- 1969 was a widespread positive PY for both fir and spruce (and also for Pinus cembra, Pinus uncinata, and Larix decidua according to Petitcolas, 1998), perhaps due to a favorable rainy spring.

Unlike negative pointer years, positive pointer years appear to be less contrasted and geographically less extended. Moreover, they are more difficult to explain using climatic data, maybe because a combination of several favorable factors is required, rather than a single extreme climatic anomaly. Some PPY were systematically observed after NPY using the Lebourgeois (1997) method of calculation, but they were the consequence of a tree recovering after a sharp growth reduction (as in 1963, 1977, 1987). Despite this drawback, this second method is more sensititive to detecting positive pointer years, due to the use of lower thresholds.

\section{Conclusion}

At the regional scale, the comparison of fir and spruce revealed that each coniferous species shows a specific pattern of 

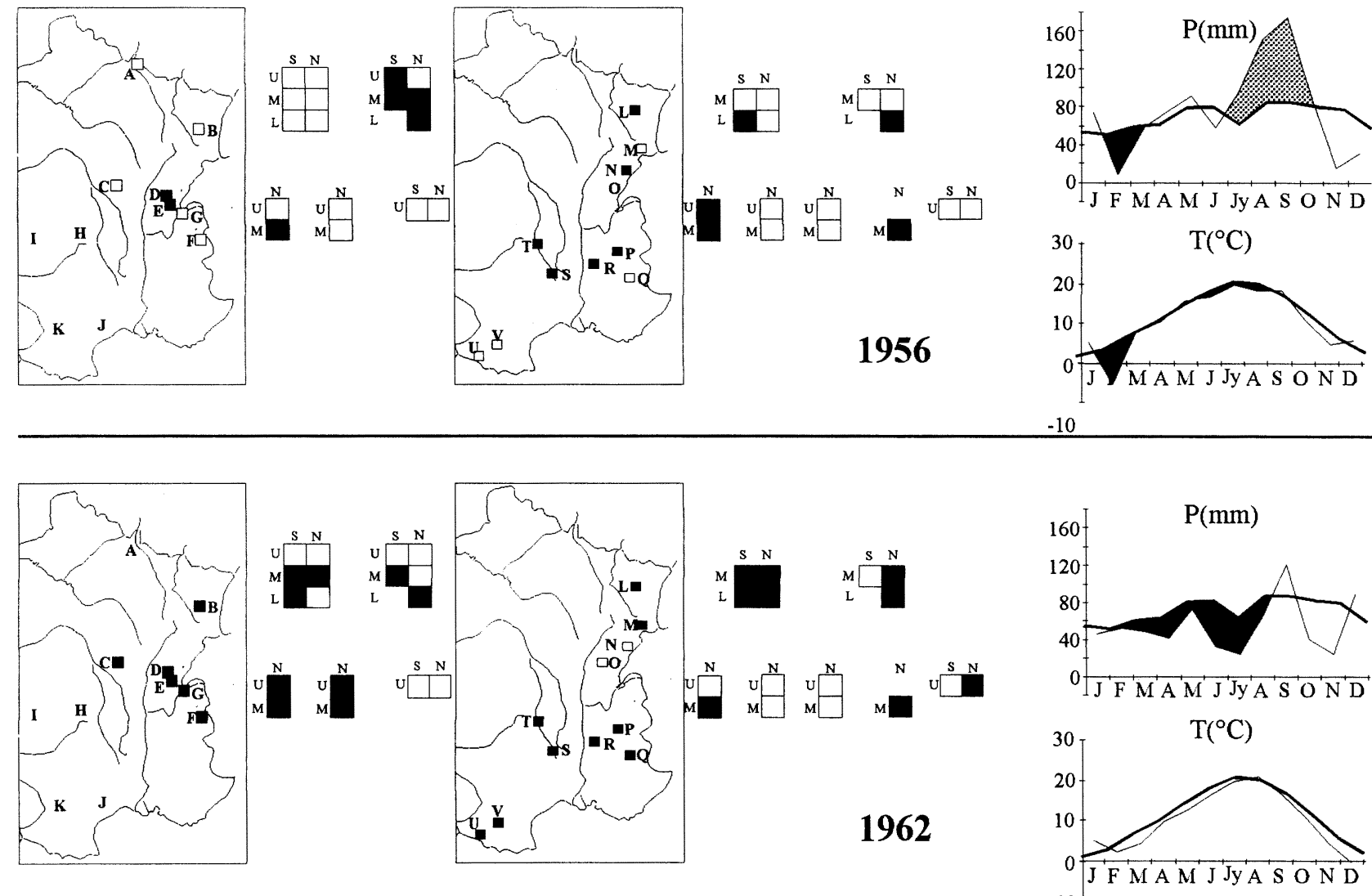
$-10^{1}$
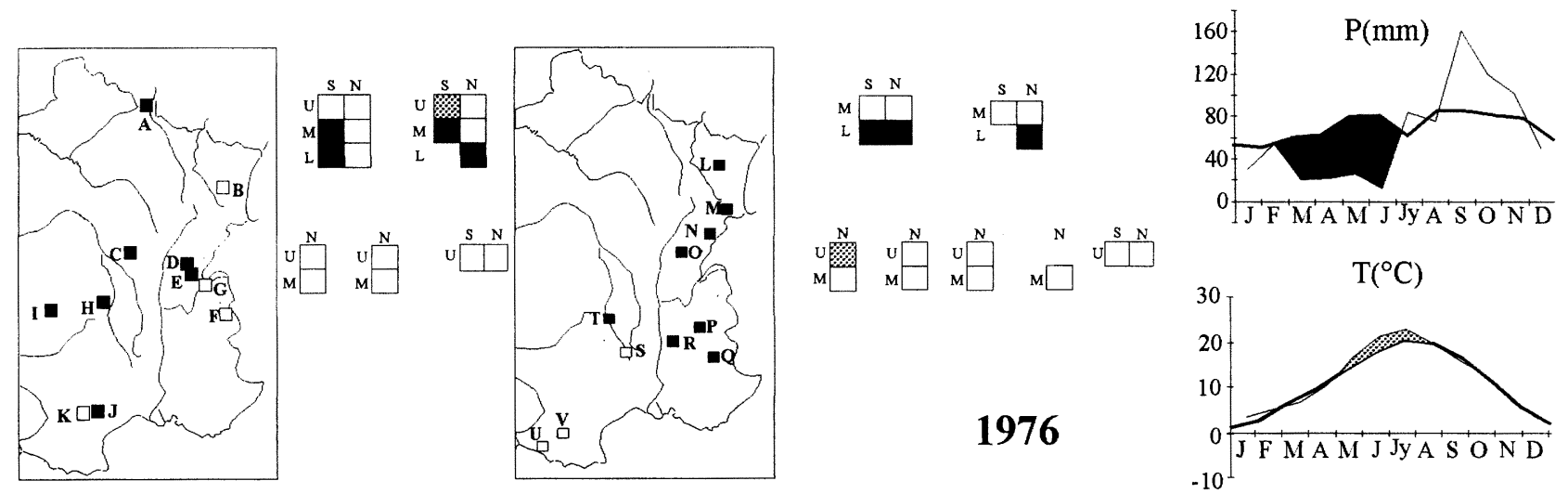

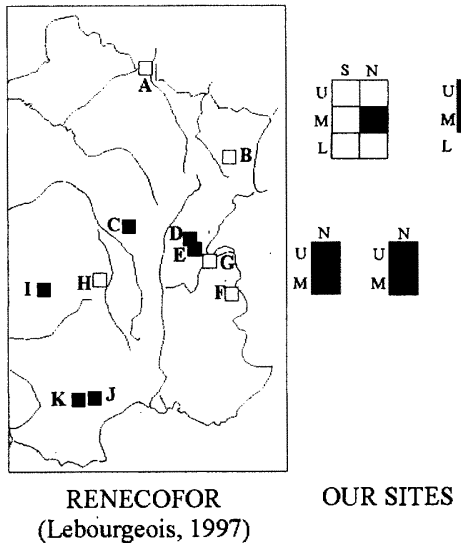

Picea abies
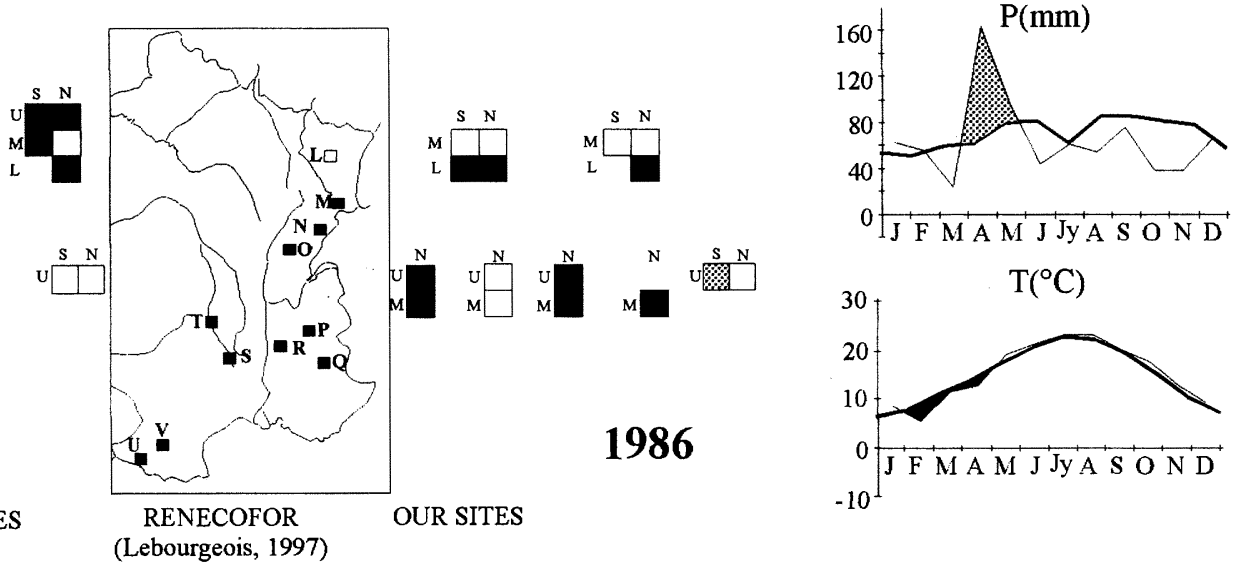

10 / Arctic, Antarctic, And Alpine Research 

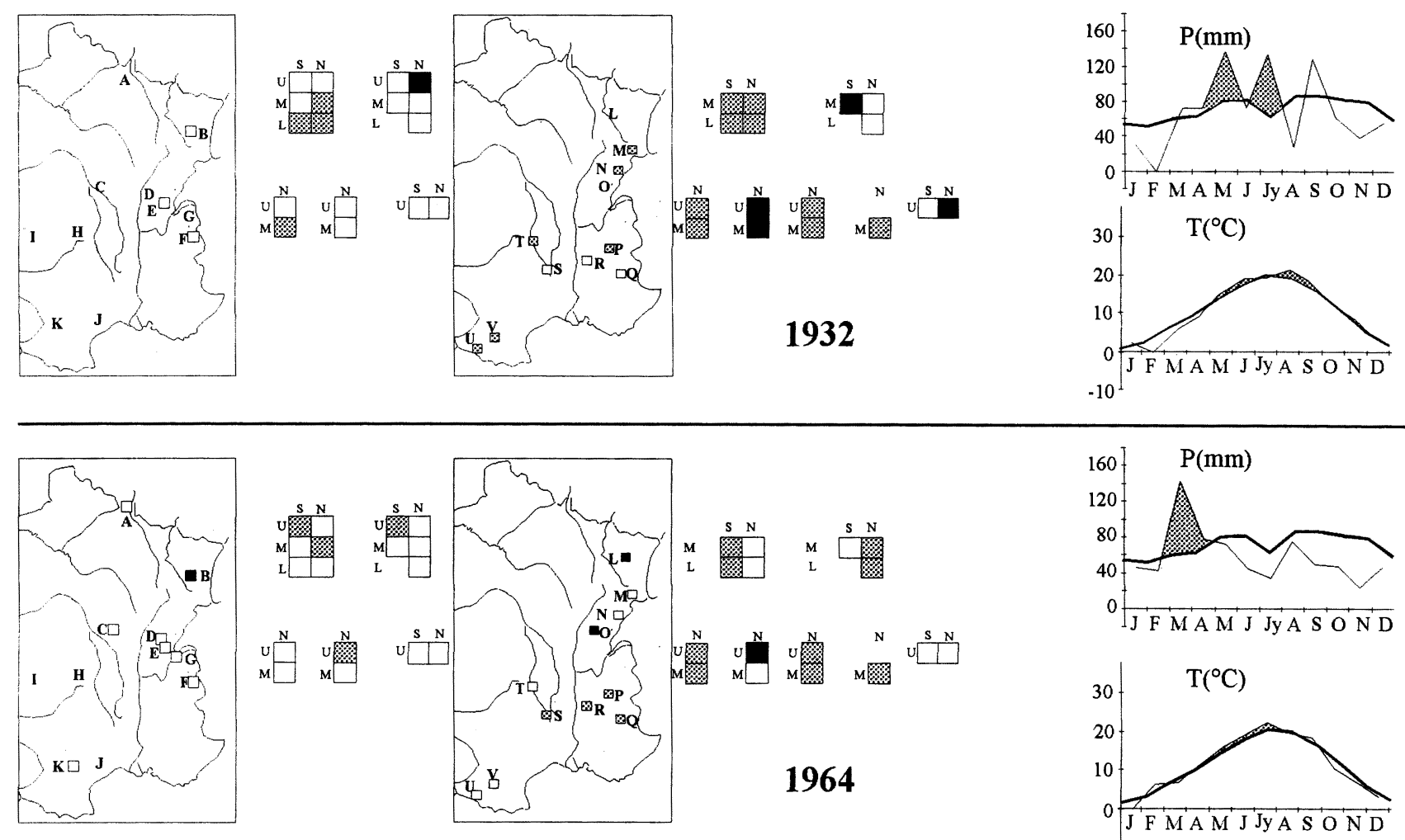
$-10$
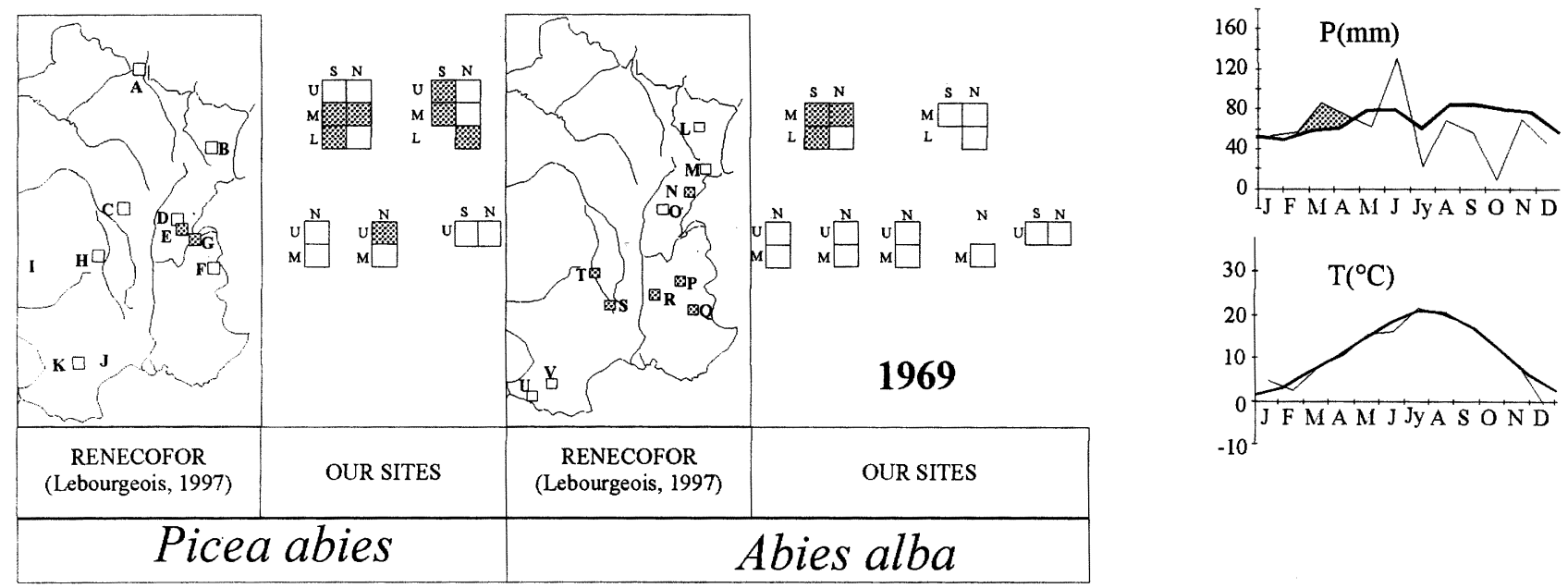

FIGURE 6. Continued.

pointer years, but some of the negative pointer years were synchronous (1921-22, 1944, 1976, 1986). Spruce presented more clear growth reductions than fir and presented specific NPY (e.g., 1948 in subalpine stands), whereas the number of growth increases was quite similar for both species (although at different dates).

Large differences appear among sites, with more negative pointer years at low altitude and southern exposure, mainly due to summer aridity. Despite a lower number of pointer years in subalpine stands, these stands should not be neglected in dendroecological studies, since cold and moist summer can also lead to extreme narrow rings (1948) or frost rings (Desplanque, 1997; Petitcolas, 1998). Competition among trees may also be involved, althrough it is difficult to take into account.

$\leftarrow$

FIGURE 6. Geographical extension of four negative pointer years in France (1956, 1962, 1976, and 1986), and three pointer years (1932, 1964, and 1969). Each square represents one sampling stand with available tree-ring data for a given year (no square if no data this year). Black and gray squares represent negative and positive pointer years, respectively. Mean monthly precipitation ( $P$ ) and temperature $(T)$ recorded in Lyon are compared with average values, calculated using the period 1921-1990 for P, and 18811990 for $T$. 
At the country scale, similarities over long distances were more extended for the negative pointer years than for the positive ones since most of them were due to single geographically extended climatic events and not to a combination of climatic peculiarities. Consequently, they are also easier to interpret. Pointer years observed in our results match well with those obtained in Vosges and Jura mountains (Bert, 1992).

At the scale of the European continent, the extreme pointer years found here were also occasionaly observed in distant areas, particularly in the Switzerland Wallis (Lingg, 1986; Schweingruber, 1986) with a dry climate, and also in Berne (Lenz et al., 1987) (e.g., 1921, 1976), in Germany (Worbes, 1989), and in the Austro-Italian Tyrol (Hüsken, 1994). However, the Italian Trentino provided less comparable results (Bronzini et al., 1989), probably due to wetter summer.

This systematic study of pointer years is the first one carried out in this part of the Alpine chain with an ecological point of view. It demonstrates the usefulness of an ecological stratified site selection, especially near the geographical limits of distribution of tree species. At regional, country and even larger scales, the pointer years method appears to be a good dendroclimatological tool to investigate the geographical variability of extreme tree-ring widths. The pointer year method also permits the analysis of the ecological requirements for the growth of particular species. Moreover, these results confirm that wood cross-dating using tree rings is possible over long distances, because the extreme tree-ring widths are geographically extended over large areas.

\section{Acknowledgments}

The authors thank Josée Lucas for technical assistance and Eileen Carey (University of Montana) for article improvement. Financial support was provided by the Rhône Alpes Region.

\section{References Cited}

Bartoli, C., 1966: Etudes écologiques sur les associations forestières de la Haute-Maurienne. Annales des Sciences Forestières, 23: 433-479.

Becker, M., 1988: The role of climate on present and past vitality of silver fir forests in the Vosges mountains of northeastern France. Canadian Journal of Forest Research, 19: 1110-1117.

Bert, G. D., 1992: Influence du climat, des facteurs stationnels et de la pollution sur la croissance et l'état sanitaire du Sapin pectiné (Abies alba Mill.) dans le Jura. Etude phytoécologique et dendroécologique. Thesis, Nancy. $200 \mathrm{pp}$.

Blanchard, R., 1922: La sécheresse en Dauphiné, 1920-1921. Grenoble: Joseph Allier $23 \mathrm{pp}$.

Bronzini, L., Gandolfo, C., and Piussi, P., 1989: Studi incrementali su Abete rosso e Abete bianco in Trentino. Dendrochronologia, 7: 51-67.

Brunstein, F. C., 1996: Climatic significance of the bristlecone pine latewood frost ring record at Almagre Mountain, Colorado, U.S.A. Arctic and Alpine Research, 28: 65-76.

Cadel, G., 1980: Séries de végétation et sols du subalpin Briançonnais sur roches mères silico-alumineuses. Comparaison avec la Maurienne et la Tarentaise. Science du sol, Bulletin de l'AFES, 4: 249-264.

Camarero, J., Guerrero-Campo, J., and Gutiérrez, E., 1998: Treering growth and structure of Pinus uncinata and Pinus sylvestris in the Central Spanish Pyrenees. Arctic and Alpine Research, 30: 1-10.

Cook, E. R. and Kairiukstis, A., 1992: Methods of Dendrochronology: Applications in the Environmental Sciences. Dordrecht: Kluwer Academic Publishers. 394 pp.

Cournoyer, L. and Filion, L., 1994: Variations in wood anatomy of white spruce in response to dune activity. Arctic and Alpine Research, 26: 412-147.

Cropper, J. P., 1979: Tree-ring skeleton plotting by computer. Tree-Ring Bulletin, 39: 47-60.

Desplanque, C., 1997: Dendroécologie comparée du sapin et de l'épicéa dans les Alpes internes Franco-Italiennes. Rôle des facteurs climatique et anthropique sur leur répartition. Thesis, Grenoble. 151 pp.

Desplanque, C., Rolland, C., and Michalet, R. 1998: Dendroécologie comparée du sapin blanc (Abies alba) et de l'épicéa commun (Picea abies) dans une vallee alpine de France. $\mathrm{Ca}$ nadian Journal of Forest Research, 28: 737-748.

Fritts, H. C., 1976: Tree-rings and Climate. London: Academic Press. $567 \mathrm{pp}$.

Gensac, P., 1988: Types de pessières et régénération en Moyenne Tarentaise. Revue Forestière Française, 40: 285-296.

Guicherd, P., 1994: Water relations of European silver fir (Abies alba Mill.) in two natural stands in the French Alps subject to contrasting climatic conditions. Annales des Sciences Forestières, 51: 599-611.

Hüsken, W., 1994: Dendrochronologische und ökologische Studien an nadelhölzern im Gebiet der Pragser Dolomiten. Dissertationes Botanicae, 215. Berlin, Stuttgart: Cramer. 183 pp.

Kaennel, M., and Schweingrüber, F. H. (Compilers) 1995: Multilingual Glossary of Dendrochronology. Terms and Definitions in English, German, French, Spanish, Italian, Portuguese and Russian. Birmensdorf, Swiss Federal Institute for Forest, Snow and Landscape Research. Berne, Stuttgart, Vienna: Haupt. 467 pp.

Kelly, P. M., Munro, M. A. R., Hughes, M. K., and Goodness, C. M., 1989: Climate and signature years in west European Oaks. Nature, 340: 57-60.

Larcher W., 1995: Physiological Plant Ecology. $3^{\text {rd }}$. ed. Berlin: Springer-Verlag. 602 pp.

Lebourgeois, F., 1997: RENECOFOR. Etude dendrochronologique des 102 peuplements du réseau. Fontainebleau: Office National des Forêts, département des recherches techniques. $307 \mathrm{pp}$.

Lenz, O., Nogler, P., and Bräcker, O. U., 1987: L'évolution du temps et le dépérissement du sapin blanc dans la région de Berne. Eidgenössische Anstalt für das forstlische Versuchwessen, 303. $44 \mathrm{pp}$.

Lepage, H. and Bégin, Y., 1996: Tree ring dating of extreme water levels events at Lake Bienville, subarctic Québec, Canada. Arctic and Alpine Research, 28: 77-84.

Lingg, W., 1986: Dendroökologische Studien an Nadelbaümen im alpinen Trockental Wallis (Schweiz). Eidgenössische Anstalt für das forstlische Versuchwessen, Berichte 287: $81 \mathrm{pp}$.

Ozenda, P., 1985: La végétation de la chaine alpine. Paris: Masson. 344 pp.

Pache, G., Michalet, R., and Aimé, S., 1996: A seasonal application of the Gams (1932) method, modified Michalet (1991): the example of the distribution of some important forest species in the Alps. Dissertationes Botanicae, 258: 31-54.

Petitcolas, V., 1998: Dendroécologie comparée de l'épicéa, du mélèze, du pin cembro et du pin à crochets en limite supérieure de la forêt dans les Alpes françaises: influence de la variabilité macroécologique. Thesis, Grenoble. $186 \mathrm{pp}$.

Rolland, C., 1993: Tree-ring and climate relationship for Abies alba in the internal Alps. Tree Ring Bulletin: 53, 1-11.

Schweingruber, F. H., 1986: Abrupt growth changes in conifers. IAWA Bulletin, 7: 277-283.

Schweingruber, F. H., Albrecht, H., Beck, M., Hessel, J., Joos, K., Keller, D., Kontic, R., Lange, K., Niederer, M., Nippel, C., Spang, S., Spinnler, A., Steiner, B., and Winkler-Seifert, A., 1986: Abrupte Zuwachsschwankungen in Jarringabfolgen als Oekologische indikatoren. Dendrochronologia, 4: 125-183.

Schweingruber, F. H., Eckstein, D., Serre-Bachet, F., and Bräcker, O. U., 1990: Identification, presentation and interpretation of 
event years and pointer years in dendrochronology. Dendrochronologia, 8: 8-38.

Schweingruber, F. H., Wehrli, U., Aellen-Rumo, K., and Aellen, M., 1991a: Weiserjahre als Zeiger extremer Standortseinflüsse. Schweizerische Zeitschrift für Forstwesen, 142: 33-52.

Schweingruber, F. H., Briffa, K. R., and Jones, P. D., 1991b: Yearly maps of summer temperatures in Western Europe from A.D. 1750 to 1975 and Western North America from 1600 to 1982: Results of a radiodensitometrical study on tree rings. Vegetatio, 92: 5-71.
Schweingruber, F. H. and Müller, M., 1992: Dendrochronological evidence in Fir and Spruce of alternating frosts in Switzerland. Dendrochronologia, 10: 23-28.

Villalba, R. and Veblen, T.T., 1994: Climatic influences on the growth of subalpine trees in the Colorado Front Range. Ecology, 75: 1450-1462.

Worbes, M., 1989: Abrupte Zuwachsreduktionen an Fichten aus dem Harz. Forst und Holz, 10: 254-259.

Ms submitted October 1998 Revised ms submitted June 1999 